\title{
Influence of macrocyclic ligands on electrolyte solvation and solubility
}

\author{
B.G. Cox \\ ICI, Fine Chemicals Manufacturing Organisation, Hexagon House, Blackley, \\ Manchester, M9 3DA, England \\ H. Schneider \\ Max-Planck-Institut für biophysikalische Chemie, 0-3400 Göttingen, FRG
}

\begin{abstract}
One of the extraordinary properties of macrocyclic compounds such as crown ethers and cryptands is their ability to dissolve/extract metal ions, including alkali ions, into non-aqueous and even nonpolar solvents. When a cation is enclosed within a macrocyclic ligand, its solvation shell is replaced by ligand donor atoms, and its exterior surface by the organic groups of the ligand. The result is the formation of an organic cation with strikingly different solubility properties. Information on the solvation energies of the complexed cations may be obtained from the changes in stability constants of the complexes in different solvents, which are related directly to the Gibbs free energies of transfer of the species involved in the complexation reaction. Analogously, a complexation equilibrium between the cation (+ anion), macrocycle, and complex (t anion) can be formulated in the solid state, and compared to the corresponding equilibrium in a solution. Once the Gibbs free energy of complexation for a given salt-ligand system is known in the solid state, the solubilities of the complexed salt in various solvents and solvent mixtures can be easily calculated. The enthalpies and entropies of complexation may be treated in a similar manner. The procedure is illustrated using measurements on $\mathrm{NaClO}_{4}, \mathrm{KClO}_{4}$, and $\mathrm{AgClO}_{4}$, and cryptand $(2,2,2)$.
\end{abstract}

\section{INTRODUCTION}

When, in 1961, Charles J. Pedersen prepared the quinquedentate ligand bis[2-(0-hydroxyphenoxy)ethyllether - (III), Scheme I - from the partially protected catechol (I) and bis(2chloroethyl)ether(II), he noticed a small residue $(0.4 \%)$ of colourless crystals, which were only very slightly soluble in methanol. However, this substance proved to be readily soluble in a methanolic solution of $\mathrm{NaOH}$. After subsequent spectrophotometric and analytical studies, Pedersen identified this substance as the macrocyclic compound $(V)$, formed by the reaction of a small amount of unprotected catechol (IV) with the ether (II). This molecule, which attracted attention in the first place because of its ability to form a complex with an alkali metal cation, was designated by Pedersen as dibenzo-18-crown-6. This name characterises, respectively, the substituent, the total number of atoms in the ring, and the number of oxygen atoms (ref. 1-3). Since then, an ever increasing number of different crown ethers and related macrocyclic ligands have been synthesised and studied, mainly in terms of their ability to complex metal ions by binding them within a central hole or cavity of the ligand.

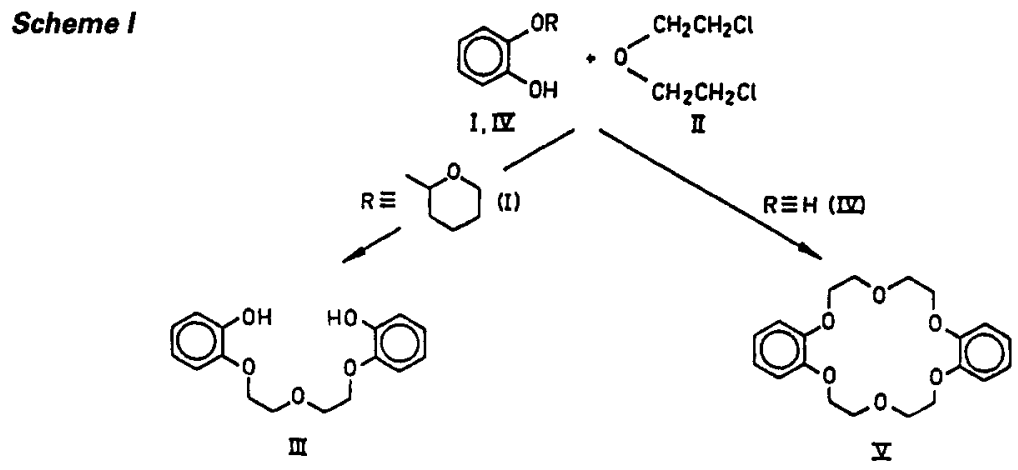


A few years later J.-M. Lehn presented a new class of ligands, the cryptands, which, being macrobicyclic polyether compounds, contain a three-dimensional, spheroidal cavity (ref. 4-6). Cryptands are able to form very strong inclusion complexes (cryptates) with cations, even the alkali metal ions, in which the bound metal ion is entirely surrounded by the ligand. Scheme II shows schematically the first cryptand to be synthesised, $(2,2,2)$ (ref. 4).

\section{Scheme II}

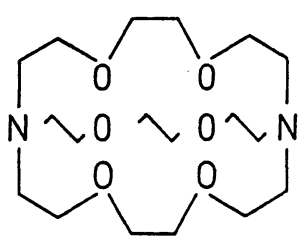

A short, and by no means exhaustive, list of the properties of crown ethers and cryptands includes the following topics:

a) selective complex formation,

b) the selective transport of cations through membranes,

c) the selective extraction of salts from aqueous to non-aqueous solvents,

d) the formation of solutions of inorganic salts in organic solvents, and

e) the reduction in ion-pair formation in low dielectric media.

The selectivities of the ligands are determined through ( $i)$ the ligand donor atoms $(0, N$, $S, \ldots)$, ( $i i)$ the overall ligand structure (monocyclic, bicyclic, cavity size), and (iii) cation-solvent and, to a lesser extent, ligand-solvent interactions.

\section{CATION SELECTIVITY OF CRYPTAND $(2,2,2)$}

In order to demonstrate in a straightforward way the influence of macrocyclic and macrobicyclic ligands on the solubility of electrolytes we restrict the discussion to complexation reactions of alkali metal and silver ions with the cryptand $(2,2,2)$ in polar solvents. The cryptand is an example of Lehn's diaza-polyether ligands and has a spheroidal cavity of estimated radius $1.4 \AA$ (ref. 5). It forms very stable inclusion complexes with alkali metal cations and $\mathrm{Ag}^{+}$, and a complexed ion of appropriate size is almost completely shielded from the surrounding medium by the organic groups of the ligand. The formation of $1: 1$ metal ion to ligand complexes (eq. 1 and $F i g .1)$ is characterized by the stability constand $K_{S}(e q .2)$

$$
\begin{aligned}
& M^{+}+(2,2,2) \rightleftharpoons M(2,2,2)^{+} \\
& K_{S}=\frac{\left[M(2,2,2)^{+}\right]}{\left[M^{+}\right][(2,2,2)]}
\end{aligned}
$$

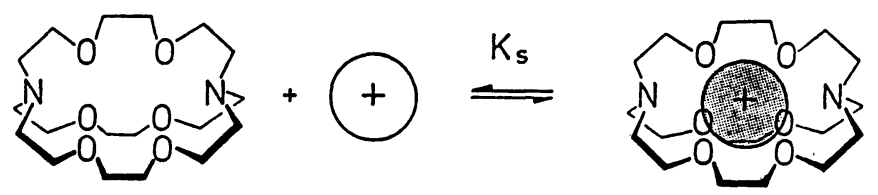

Fig. 1. Schematic representation of the complex formation between cryptand $(2,2,2)$ and a metal ion

and the thermodynamic parameters of complexation, $\Delta G_{C}^{0}, \Delta H^{0}$, and $\Delta S^{0}$ (eq. 3 ). In the case of uncharged 7 igands such as $(2,2,2)$ it is possible to use standard state thermodynamic parameters without taking into account the relevant activity coefficients appropriate to eq. 2.

$$
\begin{aligned}
\Delta G_{C}^{0} & =-2.303 R T \log K_{S} \\
\Delta G_{C}^{0} & =\Delta H_{C}^{0}-T \Delta S_{C}^{0}
\end{aligned}
$$

This is because of the preservation of charge in the complexation reaction (eq. 1 ) and the use of sufficiently dilute reactant solutions for the experimental measurements.

Table 1 lists some stability constants for complexes of $(2,2,2)$ in water and some polar solvents, and the data for alkali metal ions are presented in Fig. 2 as a function of ionic size for clarity. It is clear that, independent of solvent, the stability of the potassium cryptate, $K(2,2,2)^{7}$, is higher than those of the other cryptates in the same solvent. 
TABLE 1. Stability constants $\left(\log K_{s}\right)$ of $(2,2,2)$ cryptates in various solvents at $25^{\circ} \mathrm{C}$ (ref. 7 )

$$
\text { so } 1 \text { ven } t^{a)}
$$

\begin{tabular}{|c|c|c|c|c|c|c|c|c|}
\hline cation & $\mathrm{H}_{2} \mathrm{O}$ & $\mathrm{MeOH}$ & EtOH & PC & AN & $\left.N M^{b}\right)$ & DMF & DMSO \\
\hline $\mathrm{Li}^{+}$ & $0.9_{8}$ & 2.6 & $\leq 2.3$ & $6.9_{4}$ & 6.97 & 11.49 & - & $<1$ \\
\hline $\mathrm{Na}^{+}$ & 3.98 & $7.9_{8}$ & 8.57 & $10.5_{4}$ & 9.63 & $13.5_{6}$ & $6.1_{7}$ & 5.32 \\
\hline $\mathrm{K}^{+}$ & 5.47 & $10.4_{1}$ & $10.5_{0}$ & $11.1_{9}$ & $11.3_{1}$ & $12.5_{8}$ & 7.98 & $7.1_{1}$ \\
\hline $\mathrm{Rb}^{+}$ & 4.24 & $8.9_{8}$ & $9.2_{8}$ & $9.0_{2}$ & 9.50 & 10.3 & $6.7_{8}$ & $5.8_{5}$ \\
\hline $\mathrm{Cs}^{+}$ & $1.4_{7}$ & 4.4 & $4.1_{7}$ & $4.1_{8}$ & 4.57 & 5.7 & $2.1_{6}$ & 1.4 \\
\hline $\mathrm{Ag}^{+}$ & 9.6 & $12.2_{0}$ & $11.5_{1}$ & 16.33 & 8.99 & $17.7_{1}$ & 10.07 & $7.3_{0}$ \\
\hline
\end{tabular}

a) abbreviations: $\mathrm{MeOH}$, methanol; $\mathrm{EtOH}$, ethanol; $\mathrm{PC}$, propylene carbonate; AN, acetonitrile; NM, nitromethane; DMF, dimethyl-

b) ref. 8 formamide; DMSO, dimethyl sulfoxide

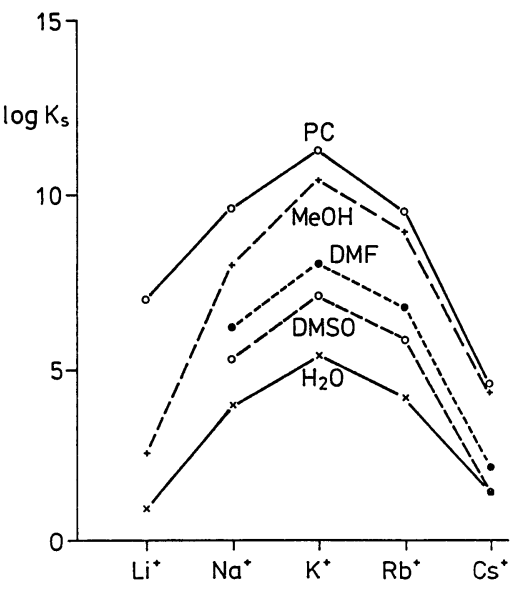

Fig. 2. Stability constants $\left(\log K_{s}\right)$ of alkali metal complexes with cryptand $(2,2,2)$ in various solvents at $25^{\circ} \mathrm{C}$

This is a reflection of the close similarity in the sizes of $K^{+}$and the cavity of $(2,2,2)$, which allows an optimal fit of this cation into the ligand cavity. The stabilities of $\mathrm{Ag}(2,2,2)^{+}$, however, are larger than those of all of the alkali metal cryptates, including $\mathrm{K}(2,2,2)^{+}$. While the latter cations interact more strongly with the ligand ether oxygen atoms than with the two nitrogen bridgehead atoms, the silver cation forms especially strong bonds with the two nitrogen atoms (ref. 9). The result is a more stable $\mathrm{Ag}^{+}$-complex in all solvents except acetonitrile, where the stability constant for $\operatorname{Ag}(2,2,2)^{+}$is lowered because of competitive interactions of the solvent nitrogen atoms with $\mathrm{Ag}^{+}$.

\section{RELATIONSHIP OF CRYPTATE FORMATION TO THE THERMODYNAMIC PARAMETERS OF METAL ION SOLVATION}

An inspection of Fig. 2 shows the marked influence of the different strengths of solvation of the species participating in the complexation reaction on the magnitude of the stability constants in the various solvents. A comparison of the reaction in water, as the usual reference solvent, with that in a non- or mixed-aqueous solvent (solv) may be conveniently discussed in terms of a thermodynamic cycle (Scheme III). In Scheme III the treatment is restricted to the perchlorate anion, but it could be readily generalised to include other anions. Moreover, although the cycle is exemplified in terms of the standard Gibbs free energy, the $\Delta G^{\circ}$ values can be replaced by the corresponding anthalpy, $\Delta H^{\circ}$, and entropy, $\Delta S^{\circ}$, terms.

\section{Scheme III}

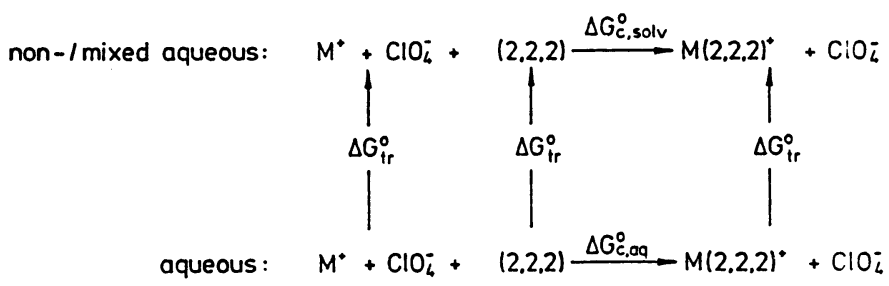

Equivalent to Scheme III is eq. 4, in which the Gibbs free energy of complexation, $\Delta G_{c}^{0}$, eq.3,

$$
\begin{aligned}
\Delta G_{c, \text { solv }}^{0}-\Delta G_{C, a q}^{0} & =\Delta G_{t r}^{0}\left(M(2,2,2)^{+}\right)-\Delta G_{t r}^{0}(2,2,2)-\Delta G_{t r}^{0}\left(M^{+}\right) \\
& =-2.303 R T \log \left\{K_{s, s o l v} / K_{s, a q}\right\}
\end{aligned}
$$

is related to the appropriate Gibbs free energies of transfer, $\Delta G_{t r}^{0}$, from water to a non- or mixed-aqueous solvent, and the complex stability constants, $K_{s}$.

A series of experimental studies (ref. 8,10-15) have been analysed in terms of Scheme III and eq. 4 is extended to include the general reference solvent, ref. It has been shown that, 
TABLE 2.

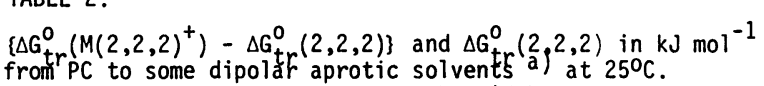

The cryptate values refer to the $\mathrm{Ph}_{4} \mathrm{As}^{+} / \mathrm{Ph}_{4} \mathrm{~B}^{-}$assumption.

s 01 ve $n \mathrm{ta}$ )

\begin{tabular}{lcccc}
\cline { 2 - 5 } cation $\mathrm{M}^{+}$ & $\mathrm{AN}$ & $\mathrm{NM}^{\mathrm{C})}$ & $\mathrm{DMF}^{\mathrm{b})}$ & $\mathrm{DMSO}^{\mathrm{b})}$ \\
\hline $\mathrm{Li}^{+}$ & 0.4 & 0.5 & - & - \\
$\mathrm{Na}^{+}$ & 3.3 & 0.0 & -0.8 & 0.3 \\
$\mathrm{~K}^{+}$ & 0.2 & 0.9 & 1.9 & 3.1 \\
$\mathrm{Rb}^{+}$ & -0.7 & 1.2 & 2.0 & 1.6 \\
$\mathrm{Cs}^{+}$ & -1.3 & 0.7 & -2.8 & 0.5 \\
$\mathrm{Ag}^{+}$ & -4.3 & 0.8 & -2.2 & 0.5 \\
$\Delta G_{\text {tr }}^{0}(2,2,2)$ & $-3.4^{\mathrm{d})}$ & $-0.9^{\mathrm{c})}$ & $-1.4^{\mathrm{d})}$ & $-1.5^{\mathrm{d})}$ \\
\hline
\end{tabular}

a) abbreviations for solvents as in Table 1

b) ref. 19

c) ref. 8

d) ref. 16

TABLE 3.

$\left.\left\{\Delta H^{0}(2,2,2)^{+}\right)-\Delta H^{0}(2,2,2)\right\}$ and $\Delta H_{+r}^{0}(2,2,2)$ in $\mathrm{kJ} \mathrm{mol}^{-1}$ from $\mathrm{PC}$ to some dipdrar aprotic solvehtsa) at $25^{\circ} \mathrm{C}$. The cryptate values refer to the $\mathrm{Ph}_{4} \mathrm{As}^{+} / \mathrm{Ph}_{4} \mathrm{~B}^{-}$assumption.

$$
\text { sol } v \text { e } n t^{a)}
$$

\begin{tabular}{lcccc}
\cline { 2 - 5 } cation $\mathrm{M}^{+}$ & $\mathrm{AN}^{\mathrm{b})}$ & $\mathrm{NM}^{\mathrm{c})}$ & $\mathrm{DMF}^{\mathrm{b})}$ & $\mathrm{DMSO}^{\mathrm{b})}$ \\
\hline $\mathrm{Li}^{+}$ & 2.6 & -1.6 & - & - \\
$\mathrm{Na}^{+}$ & -1.9 & -1.7 & 1.4 & 3.1 \\
$\mathrm{~K}^{+}$ & -0.4 & -0.9 & -0.1 & -1.1 \\
$\mathrm{Rb}^{+}$ & -2.0 & -3.5 & -0.3 & 1.2 \\
$\mathrm{Cs}^{+}$ & -2.1 & -3.1 & 1.4 & 1.3 \\
$\mathrm{Ag}^{+}$ & -1.3 & - & 2.5 & 2.1 \\
$\Delta \mathrm{H}_{\text {tr }}^{0}(2,2,2)$ & -1.6 & -3.1 & 0.1 & 1.1 \\
\end{tabular}

a) abbreviations for solvents as in Table 1

b) ref. 16

c) ref. 17

provided protic solvents are excluded, eq. 4 can be written to a very good approximation as eq. 5 . Thus the contributions to eq. 4 of the cryptate and the cryptand almose completely

$$
\Delta G_{C, \text { solv }}^{0}-\Delta G_{C, \text { ref }}^{0}=\Delta G_{\text {tr }}^{0}\left(M^{+}\right)
$$

cancel, and as long as the ligand has sufficient steric rigldity, as is the case for $(2,2,2)$, and the cation size is numerically similar to that of the ligand cavity, eq. 6 is valid (Table 2). Corresponding equations (eq. 7 and 8 ) have been shown to apply to the enthalpies

$$
\begin{aligned}
\Delta G_{\operatorname{tr}}^{0}\left(M(2,2,2)^{+}\right) & =\Delta G_{\operatorname{tr}}^{0}(2,2,2) \\
\Delta H_{\text {c,solv }}^{0}-\Delta H_{C, \text { ref }}^{0} & =\Delta H_{t r}^{0}\left(M^{+}\right) \\
\Delta H_{t r}^{0}\left(M(2,2,2)^{+}\right) & =\Delta H_{t r}^{0}(2,2,2)
\end{aligned}
$$

of complexation and transfer (ref. 16-18) (Table 3) and hence of course also to the entropies. Therefore, eq. 5 and 7 may be used as extrathermodynamic assumptions to estimate ionic thermodynamic parameters of transfer between two aprotic, polar solvents.

The so-called cryptate hypothesis (eq. 6 and 8 ) holds adequately even for $\mathrm{Cs}^{+}$complexes with $(2,2,2)$ in dipolar aprotic solvents, al though there is unquestionable evidence from ${ }_{133}$ Cs-NMR chemical shift measurements (ref. 20) that $\mathrm{Cs}^{+}$forms exclusive as well as inclusive complexes with $(2,2,2)$ in acetone, propylene carbonate, and dimethylformamide. In an exclusive complex the cation is only partially accommodated within the ligand cavity and therefore, in principle, may interact directly with the solvent.

\section{SOLUBILITIES AND SOLID STATE COMPLEXATION OF METAL SALTS WITH CRYPTAND $(2,2,2)$}

The Gibbs free energies of transfer, $\Delta G^{0}$, in Scheme III are normally defined as the difference between the Gibbs free energies of hydration of the species and their Gibbs free energies of solvation in a non- or mixed-aqueous solvent. However, $\Delta G^{0}$, can equally well be expressed as the difference of the Gibbs free energies of solution in ${ }^{\prime}$ non- or mixedaqueous solution, and in water. Thus Scheme III can be modified to embrace the solid state in addition to the aqueous solution (Scheme IV). The Gibbs free energies for the solid state complexation reaction may then be obtained via the thermodynamic cycle in Scheme IV, provided the free energies of solution of $(2,2,2)$ and the simple and complexed salts are known.

Scheme IV

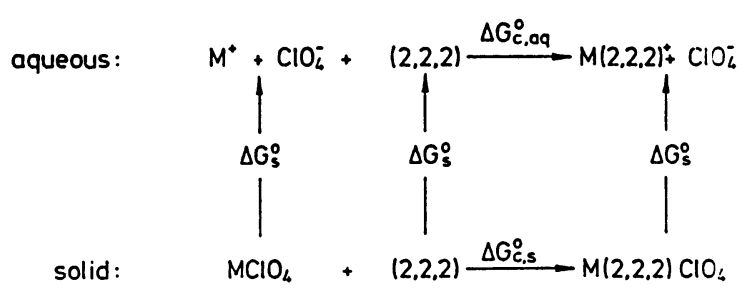

The required Gibbs free energy of solution of $(2,2,2)$ in water $\left(\Delta G_{c}^{0}=5.0 \pm 0.7 \mathrm{~kJ} \mathrm{~mol}^{-1}\right)$ has been calculated independently from the solubilities of the cryptand in cyclohexane $(0.238 \mathrm{M})$ and tetradecane $(0.086 \mathrm{M})$, combined with the known partition coefficients $($ ref. 21$)$ 
for distribution of $(2,2,2)$ between the two solyents and water. The Gibbs free energies of solution of the metal perchlorates in water, $\Delta G_{(}\left(\mathrm{MClO}_{4}\right)$, follow from the NBS compilations of the Gibbs free energies of formation, $\Delta G_{f}\left(M_{C P O}\right)$, of the salts in the crystalline and aqueous states (ref. 22). The Gibbs free energies of solution of the complexed salts, $\mathrm{M}(2,2,2) \mathrm{ClO}_{4}$, for $\mathrm{M}^{+}=\mathrm{Na}^{+}, \mathrm{K}^{+}$, and $\mathrm{Ag}^{+}$, have been obtained from their solubilities in water.

Inserting these quantities and the stability constants (as $\Delta G^{0}{ }^{0}$ ) for the complexes in water (Table 1) into eq. 9 (an alternative representation of Scheme IV) allows calculation

$$
\Delta G_{C, s}^{0}=\Delta G_{c, a q}^{0}+\Delta G_{s}^{0}\left(M C 10_{4}\right)+\Delta G_{s}^{0}(2,2,2)-\Delta G_{s}^{0}\left(M(2,2,2) C 10_{4}\right)
$$

of the Gibbs free energy of complexation for the solid state reaction $\left(\Delta G_{c, s}^{0}\right)$. This is exemplified for $\mathrm{KClO}_{4}$ and $(2,2,2)$ in Scheme $\mathrm{V}$.

\section{Scheme $V$}

Gibbs free energy $\left(\mathrm{kJ} \mathrm{mol}{ }^{-1}\right) ; 25^{\circ} \mathrm{C}$

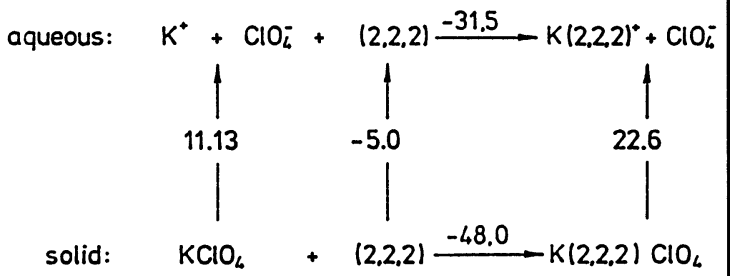

$\log K_{\mathrm{s}, \mathrm{aq}}=5,53 \quad: \quad \log \mathrm{K}_{\mathrm{s}, \mathrm{s}}=8,4$
Scheme VI

Enthalpy $(\mathrm{kJ} \mathrm{mol}-1): 25^{\circ} \mathrm{C}$

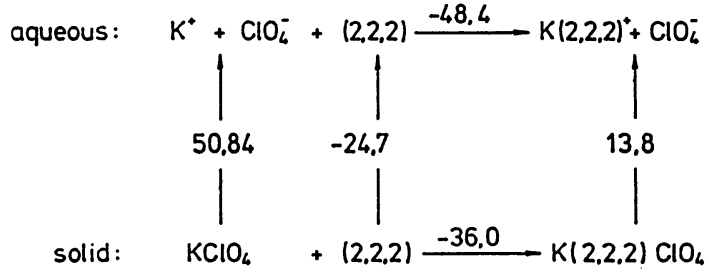

The enthalpies of coordination in the solid state have been calculated in a similar manner using ( $i$ ) the enthalpies of solution of $(2,2,2)$ and of the above mentioned alkali metal cryptate salts in water (ref. 21 ), (ii) the enthalpies of formation of the metal perchlorate salts in the crystalline and aqueous state (ref. 22), and ( $j i i$ ) the enthalpies of complexation in water (ref. 21 ), $\Delta H_{c, a q}$. The numerical values are included in Scheme VI.

The Gibbs free energies, enthalpies, and entropies of coordination for the $(2,2,2)$ cryptates of $\mathrm{NaClO}_{4}, \mathrm{KClO}_{4}$, and $\mathrm{AgClO}_{4}$ in the solid state are listed in Table 4.

TABLE 4. Gibbs free energies, enthalpies and entropies of coordination in the solid state at $25^{\circ} \mathrm{C}$

\begin{tabular}{lccc}
$\mathrm{M}(2,2,2) \mathrm{ClO}_{4}$ & $\begin{array}{c}\Delta \mathrm{G}_{\mathrm{C}, \mathrm{s}}^{0} \\
\mathrm{~kJ} \mathrm{~mol}\end{array}$ & $\begin{array}{c}\Delta \mathrm{H}_{\mathrm{C}, \mathrm{s}}^{0} \\
\mathrm{~kJ} \mathrm{~mol}\end{array}$ & $\begin{array}{c}\Delta \mathrm{S}_{\mathrm{C}, \mathrm{s}}^{0} \\
\mathrm{JK}^{-1} \mathrm{~mol}^{-1}\end{array}$ \\
\hline $\mathrm{Na}(2,2,2) \mathrm{ClO}_{4}$ & -67.4 & -59.2 & 28 \\
$\mathrm{~K}(2,2,2) \mathrm{ClO}_{4}$ & -48.0 & -36.0 & 40 \\
$\mathrm{Ag}(2,2,2) \mathrm{ClO}_{4}$ & -100.2 & - & - \\
\hline
\end{tabular}

The expression of the Gibbs free energy of coordination, $\Delta G^{0}$, as an equilibrium constant for the system solid salt, ligand, and cryptate salt, which ${ }^{C}$ hás been done in Scheme $V$ for $K(2,2,2) C 10$, gives rise to a value which is not dramatically different from the stability constants observed in solution (Table 1). The only striking differences in the thermodynamic parameters for coordination in the liquid and solid states are found in the entropies of coordination (Tables 5 and 6 ). The entropies of coordination in solution are almost invariable negative for the reactions in solution, whereas for the solid state reactions, $\Delta \mathrm{S}_{\mathrm{C}, \mathrm{s}}$, values are in both cases substantial and positive.

In solution very positive entropies of coordination are associated with the reactions of small, heavily solvated cations, and they may be explained fairly simply in terms of the release of strongly bound solvent molecules from the rigidly ordered cationic solvation spheres when the cryptate is formed. This interpretation is supported by the observed linear dependence of the entropy of cryptation, $\Delta S^{0}$, with $(2,2,2)$ upon the cationic entropy of solvation for several univalent salts in non-aque ous solvents (ref. 25). An exact analogy in the solid state is not possible, but one source of increased entropy may be the weakening of the electrostatic interaction between the cation and the anion $\left(\mathrm{ClO}_{4}^{-}\right)$in the cryptate salt relative to the simple salt. 
TABLE 5. Thermodynamic parameters for the complexation reaction $\mathrm{K}^{+}+(2,2,2) \rightarrow K(2,2,2)^{+}$at $25^{\circ} \mathrm{C}$

\begin{tabular}{|c|c|c|c|c|}
\hline medium & $\log k_{s}$ & $\begin{array}{l}\Delta G_{\mathrm{C}}^{0} \\
\mathrm{~kJ} \mathrm{~mol}^{-1}\end{array}$ & $\begin{array}{l}\Delta H_{\mathrm{C}}^{0} \\
\mathrm{~kJ} \mathrm{~mol}^{-1}\end{array}$ & $\mathrm{JK}^{-1} \mathrm{~mol}^{0}$ \\
\hline sol id $\left.{ }^{a}\right)$ & 8.4 & -48.0 & -36.0 & 40.3 \\
\hline water & $5.5_{2}^{b)}$ & -31.5 & $-48.4^{c)}$ & -56.6 \\
\hline $\mathrm{MeOH}$ & $10.4^{d)}$ & -59.4 & $-71.3^{c)}$ & -39.9 \\
\hline PC & $11.1_{g}{ }^{d)}$ & -63.9 & $-71.9^{e)}$ & -26.8 \\
\hline AN & $11 \cdot 3_{1}$ d) & -64.6 & $-71.3^{\mathrm{e})}$ & -22.5 \\
\hline NM & $12.5_{8}^{9)}$ & -71.8 & $-80.3^{f)}$ & -28.5 \\
\hline DMF & $7.9_{8}^{d)}$ & -45.6 & $-54.5^{g)}$ & -29.9 \\
\hline DMSO & $7.1_{1}{ }^{d)}$ & -40.6 & $-61.2^{g)}$ & -69.1 \\
\hline
\end{tabular}

a) anion: $\mathrm{ClO}_{4}^{-}$, b) ref. 23, c) ref. 21 , d) ref. 7 , e) ref. $16, f$ ) ref. $8, g)$ ref. 24
TABLE 6. Thermodynamic parameters for the complexation reaction $\mathrm{Na}^{+}+(2,2,2) \longrightarrow \mathrm{Na}(2,2,2)^{+}$at $25^{\circ} \mathrm{C}$

\begin{tabular}{|c|c|c|c|c|}
\hline medium & $\log k_{s}$ & ${ }_{\mathrm{kJ} \mathrm{mol}^{-1}}^{\Delta G_{\mathrm{C}}^{0}}$ & $\begin{array}{l}\Delta H_{\mathrm{C}}^{0} \\
\mathrm{~kJ} \mathrm{~mol}^{-1}\end{array}$ & $\mathrm{JK}^{-{ }^{-1} \mathrm{~mol}^{\mathrm{C}}}{ }_{\mathrm{mol}}^{-1}$ \\
\hline solida) & 11.8 & -67.4 & -59.2 & 27.6 \\
\hline water & $3.98^{b)}$ & -22.7 & $-31.9^{c)}$ & -30.9 \\
\hline $\mathrm{MeOH}$ & $7.9_{8}^{b)}$ & -45.6 & $-44.6^{c)}$ & 3.4 \\
\hline PC & $10.5_{4}^{b)}$ & -60.2 & $-64.1^{d)}$ & -12.7 \\
\hline AN & $9.6_{3}^{b)}$ & -55.0 & $-61.0^{d)}$ & -53.7 \\
\hline NM & $\left.13.5_{6} \mathrm{e}\right)$ & -77.4 & $-85.7^{f)}$ & -27.8 \\
\hline DMF & $6.17^{b)}$ & -35.2 & $-40.0^{9)}$ & -16.1 \\
\hline DMSO & $5.3_{2}^{(b)}$ & -30.3 & $-44.6^{9)}$ & -48.0 \\
\hline
\end{tabular}

a) anion: $\left(10_{4}^{-}\right.$, b) ref. 7, c) ref. 21 , d) ref. 16 , e) ref. 8, f) ref. 17, g) ref. 24

\section{EFFECT OF CRYPTATE FORMATION ON ELECTROLYTE SOLUBILITY IN PURE SOLVENTS}

A combination of Schemes III and IV leads to a thermodynamic double-cycle in which the equilibria of cryptate formation in the solid state are related to the corresponding processes in aqueous and in non- or mixed-aqueous liquid states. Various routes around this cycle may then be used to calculate the solubilities of a cryptate salt in any solvent (solv), as, for example, in eq. 10. This shows the determination of the solubility product from the stability

$$
\begin{aligned}
-2.303 \text { RT } \log K_{S p, s o l v}^{0}\left(M(2,2,2) C 10_{4}\right)= & \Delta G_{s, s o l v}^{0}\left(M(2,2,2) C 10_{4}\right) \\
= & \Delta G_{s, a q}^{0}\left(M(2,2,2) C 10_{4}\right)+\Delta G_{t r}^{0}\left(M(2,2,2) C 10_{4}\right) \\
= & \left\{\Delta G_{s, a q}^{0}\left(M C 10_{4}\right)+\Delta G_{t r}^{0}\left(M C 10_{4}\right)\right\}+ \\
& \left\{\Delta G_{s, a q}^{0}(2,2,2)+\Delta G_{t r}^{0}(2,2,2)\right\}- \\
& 2.303 R T \log \left\{K_{s, s o l v} / K_{s, s}\right\}
\end{aligned}
$$

constant for cryptate formation, the Gibbs free energy of solution (Scheme IV), and the Gibbs free energies of transfer (Scheme III). Table 7 lists solubility products calculated in this way for $\mathrm{Na}(2,2,2) \mathrm{ClO}_{4} \cdot \mathrm{K}(2,2,2) \mathrm{ClO}_{4}$, and $\mathrm{Ag}(2,2,2) \mathrm{ClO}_{4}$ in several pure solvents. Solubility products for the uncomplexed salts have also been included for comparison.

The changes in solubility products due to cryptate formation may be in direction of either

\begin{tabular}{|c|c|c|c|c|c|c|}
\hline solv. b) & $\begin{array}{l}\operatorname{logk}_{\mathrm{sp}}^{0} \text { of } \\
\left(\mathrm{NaClO}_{4}\right)\end{array}$ & $\begin{array}{l}\operatorname{logk}_{\mathrm{Sp}}^{0} \text { of } \\
\left(\mathrm{Na}(2,2,2) \mathrm{ClO}_{4}\right)\end{array}$ & $\mid \begin{array}{l}\log _{\mathrm{Sp}}^{0} \\
\left(\mathrm{KClO}_{4}\right)\end{array}$ & $\left|\begin{array}{l}\operatorname{logk}_{\mathrm{Sp}}^{0} \text { of } \\
\left(\mathrm{K}(2,2,2) \mathrm{ClO}_{4}\right)\end{array}\right|$ & $\mid \begin{array}{l}\log \mathrm{K}_{\mathrm{sp}}^{0} \text { of } \\
\left(\mathrm{AgCiO}_{4}\right)\end{array}$ & $\mid \begin{array}{l}\log K_{s p}^{0} \text { of } \\
\left(\mathrm{Ag}(2,2,2) \mathrm{ClO}_{4}\right)\end{array}$ \\
\hline water & 2.79 & -4.17 & -1.95 & -3.97 & 3.37 & -3.71 \\
\hline $\mathrm{MeOH}$ & 0.14 & -3.56 & -4.81 & -2.46 & 0.97 & -4.34 \\
\hline EtOH & -1.42 & -4.70 & -6.86 & -4.46 & 0.38 & -5.81 \\
\hline PC & -1.28 & -2.60 & -4.53 & -1.74 & -1.36 & -2.62 \\
\hline AN & 0.11 & -6.33 & -3.53 & -0.55 & 7.10 & -0.71 \\
\hline NM & -3.57 & -2.18 & -5.48 & -1.61 & - & - \\
\hline DMSO & 5.61 & -1.11 & 0.75 & -0.73 & 9.68 & -0.89 \\
\hline DMF & 3.61 & -2.26 & -1.28 & -1.90 & 5.58 & -2.32 \\
\hline
\end{tabular}
increased or decreased solubility, depending upon the salt and solvent. The effects may be very large indeed with differences of up to ten orders of magnitude being observed. The most obvious generalisation following from these results is that the solubilities of the more

TABLE 7. Solubility products $\left(\log _{\mathrm{K}}^{\mathrm{O}}\right.$ ) of $\mathrm{NaClO}_{4}, \mathrm{KClO}_{\mathrm{S}} \mathrm{CagClO}_{4}$ and their

a) $-2.303 \mathrm{RT} \log \mathrm{K}_{\mathrm{Sp}}^{0}\left(\mathrm{MClO}_{4}\right)=\Delta G_{\mathrm{S}}^{0}\left(\mathrm{MClO}_{4} ; \mathrm{aq}\right)+\Delta G_{\mathrm{tr}}^{0}\left(\mathrm{MClO}_{4}\right)$

$-2.303 R T \log K_{S p}^{0}\left(M(2,2,2) C 10_{4}\right)=\Delta G_{s}^{0}\left(M(2,2,2) C 10_{4} ; a q\right)+\Delta G_{t r}^{0}\left(M(2,2,2) C 10_{4}\right)$ The $\Delta G_{t r}^{0}$ values have been taken from Table III and Table IV of ref. 7 . The iodides have been converted into perchlorates with $\left\{\Delta G_{t r}^{0}\left(\mathrm{ClO}_{4}^{-}\right)-\Delta G_{t r}^{0}\left(I^{-}\right)\right\} /$ kJ mol ${ }^{-1}:-0.80, \mathrm{MeOH} ;-1.70$, EtOH; $-6.60, \mathrm{PC} ;-17.1, \mathrm{AN} ;-14.5, \mathrm{DMSO} ;-14.8$, DMF

b) abbreviations for solvents as in Table 1 
soluble salts (irrespective of solvent) are reduced upon cryptate formation and vice versa for sparingly soluble salts ( $\mathrm{Table} 7 \mathrm{e} . \mathrm{g} . \mathrm{NaClO}_{4}\left(\mathrm{H}_{2} \mathrm{O}\right), \mathrm{AgClO}_{4}\left(\mathrm{H}_{2} \mathrm{O}\right), \mathrm{KClO}_{4}$ (DMSO) vs. $\mathrm{NaClO}_{4}$ (NM), $\mathrm{KClO}_{4}(\mathrm{PC})$, etc.). It is also noticeable that for a given salt in different solvents, the solubility of the cryptate salt increases relative to that of the uncomplexed salt as the solvating ability of the solvent (as measured by the absolute solubility of the salt) decreases. This is a reflection of the comparative insensitivity of the complexed cation to solvent variation. An important consequence is that cryptate formation will often have a beneficial effect on electrolyte solubility in weakly solvating media.

\section{EFFECT OF CRYPTATE FORMATION ON ELECTROLYTE SOLUBILITY IN MIXED SOLVENTS}

Complex formation between $(2,2,2)$ and $\mathrm{K}^{+}$and $\mathrm{Ag}^{+}$, two cations of almost the same size, has been studied recently in mixtures of acetonitrile and water (ref. 26,27). The Gibbs free energies of transfer of $\mathrm{K}(2,2,2) \mathrm{ClO}$ and $\mathrm{Ag}(2,2,2) \mathrm{ClO}$ have been calculated over the whole mole fraction range using the stabifity constants or Gibbs free energies of complexation (see Scheme III). The results are shown in Fig. 3 , along with values for $(2,2,2), \mathrm{KClO}_{4}$, and $\mathrm{AgClO}_{4} \cdot$

The remarkable difference between $\Delta G^{0}\left(\mathrm{AgClO}_{4}\right)$ and $\Delta G^{0}\left(K C 10_{4}\right)$ is a result of a very strong interaction between $\mathrm{Ag}^{+}$and acetonitrifle on the one hathd, leading to a decrease in free energy with increasing mole fraction, $x_{A N}$, of acetonitrile, and a preferential hydration of $\mathrm{K}^{+}$on the other hand, causing an increase in $\Delta G_{\mathrm{H}}^{0}\left(\mathrm{KClO}_{4}\right)$ with increasing $\mathrm{X}_{A N}$. However, the corresponding values for the complexed salts, $\operatorname{Ag}(2,2,2) \mathrm{ClO}_{4}$ and $\mathrm{K}(2,2,2) \mathrm{ClO}$, differ only slightly by comparison. These results provide an excellent illustration of the ability of the ligand to shield the enclosed cation from direct, specific interaction with the solvent.

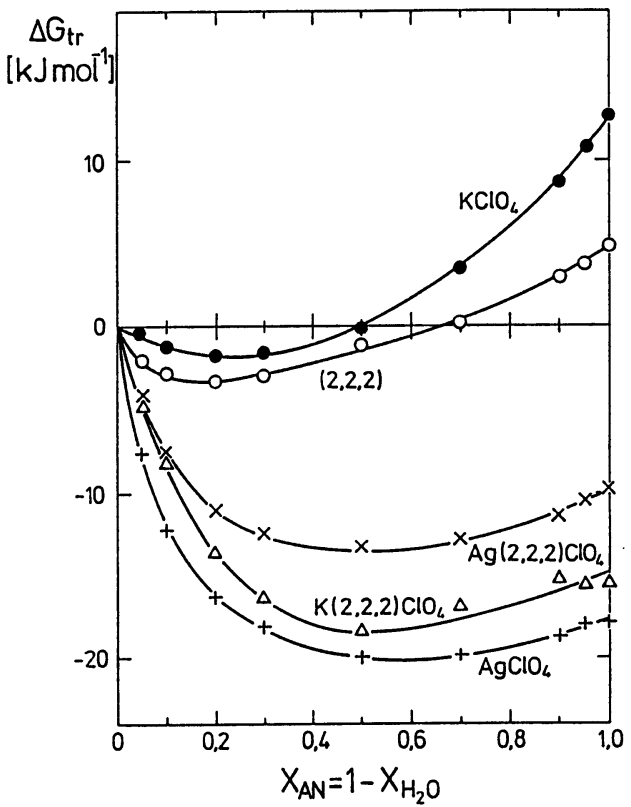

Fig. 3. Gibbs free energies of transfer of $(2,2,2), \mathrm{KClO}_{4}, \mathrm{AgClO}_{4}$ and the corresponding cryptate salts in acetonitrile + water mixtures at $25^{\circ} \mathrm{C}$

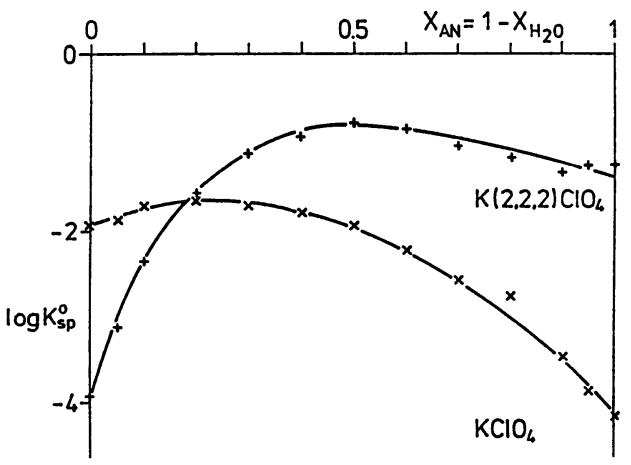

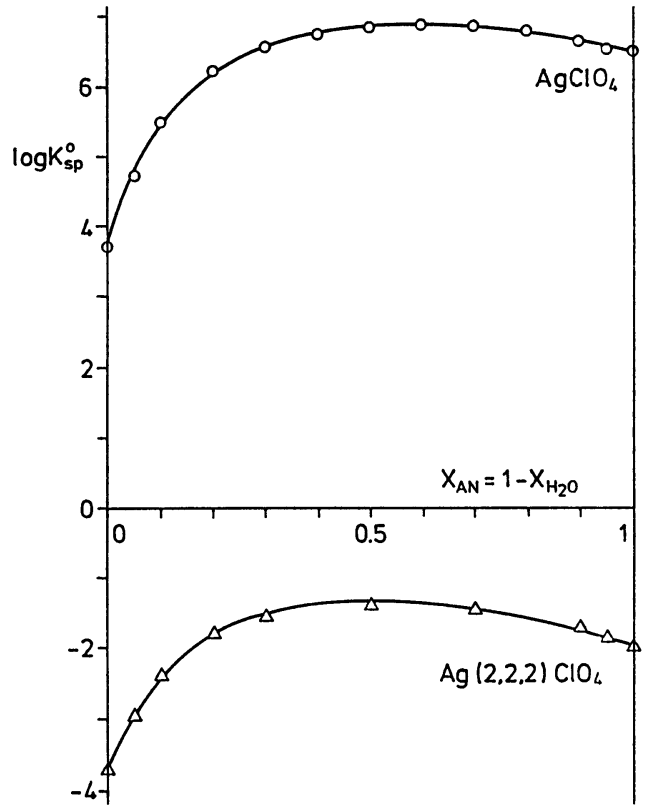

Fig. 4. Solubility products $\left(\log \mathrm{K}_{\mathrm{sp}}^{0}\right)$ of $\mathrm{AgClO}_{4}$ and $\mathrm{Ag}(2,2,2) \mathrm{ClO}_{4}$ in acetonitrile ${ }_{+}^{\mathrm{sp}}$ water mixtures at $25^{\circ} \mathrm{C}$

Fig. 5. Solubility products $\left(\log K_{S p}^{0}\right)$ of $\mathrm{KClO}_{4}$ and $\mathrm{K}(2,2,2) \mathrm{ClO}_{4}$ in acetonitrile + water mixtures at $25^{\circ} \mathrm{C}$ 
TABLE 8. Solubility products of $\mathrm{KClO}_{4}, \mathrm{AgClO}_{4}$ and their $(2,2,2)$ cryptates in acetonitrile + water mixtures at $25^{\circ} \mathrm{C}$

\begin{tabular}{|c|c|c|c|c|}
\hline$x_{A N}=1-x_{H_{2}} 0$ & $\left|\log \mathrm{K}_{\mathrm{sp}}^{0}\left(\mathrm{AgClO}_{4}\right)\right|$ & $\log _{\mathrm{sp}}^{0}\left(\mathrm{Ag}(2,2,2) \mathrm{ClO}_{4}\right)$ & $\log _{\mathrm{Sp}}^{0}\left(\mathrm{KClO}_{4}\right)$ & $\operatorname{logk}_{s p}^{0}\left(K(2,2,2) \mathrm{ClO}_{4}\right)$ \\
\hline 0.0 & $3.37_{3}$ & -3.71 & -1.95 & -3.97 \\
\hline 0.05 & $4.7_{2}$ & -2.97 & -1.88 & $-3.1_{3}$ \\
\hline 0.1 & $5.5_{1}$ & $-2.4_{1}$ & $-1.7_{3}$ & -2.35 \\
\hline 0.2 & $6.2_{3}$ & -1.78 & $-1.6_{5}$ & -1.58 \\
\hline 0.3 & $6.5_{4}$ & -1.54 & $-1.7_{0}$ & $-1.1_{1}$ \\
\hline 0.4 & $6.7_{5}$ & - & -1.79 & $-0.9_{2}$ \\
\hline 0.5 & $6.8_{8}$ & $-1.4_{0}$ & $-1.9_{4}$ & $-0.7_{6}$ \\
\hline 0.6 & $6.8_{9}$ & - & -2.22 & $-0.8_{3}$ \\
\hline 0.7 & 6.86 & $-1.4_{8}$ & -2.57 & $-1.0_{2}$ \\
\hline 0.8 & 6.79 & - & $-2.9_{6}$ & $-1.1_{6}$ \\
\hline 0.9 & $6.6_{5}$ & $-1.7_{3}$ & -3.48 & -1.32 \\
\hline 0.95 & $6.5_{3}$ & -1.89 & $-3.8_{6}$ & -1.25 \\
\hline 1.0 & و6.6 & و. & $-4.1_{7}$ & -1.25 \\
\hline
\end{tabular}

The solubility products of $\mathrm{AgClO}_{4}, \mathrm{KClO}_{4}, \mathrm{Ag}(2,2,2) \mathrm{ClO}_{4}$, and $\mathrm{K}(2,2,2) \mathrm{ClO}_{4}$ (Table 8 ) have been calculated in the solvent mixtures using the procedure outlined in the previous section, and these are plotted against the mole fraction of acetonitrile in Figs. 4 and 5 . There is a dramatic charige of about eight orders of magnitude in the solubility products of $\mathrm{AgClO}_{4}$ in the solvent mixtures on complex formation (Fig. 4). However, the relative variation with ${ }^{4}$ solvent composition is preserved. Thus, the preferential solvation of $\mathrm{Ag}^{+}$by acetonitrile and the increasing interaction of $\mathrm{Ag}(2,2,2)^{+}$with solvent in the more organic solutions, both lead to an increase in $K_{S p}$ with mole fraction $x_{A N}$.

In the case of the two potassium salts the $\mathrm{pK}_{\mathrm{SP}}^{0}$ curves intersect at $\mathrm{x}_{A N}=0.2$. The solubility products of the salts in water differ 角ich less than those of the two silver salts, and the preferential hydration of $\mathrm{K}^{+}$and solvation by acetonitrile of $\mathrm{K}(2,2,2)^{+}$, which have opposite effects on the solubilities of the salts with increasing $x_{A N}$, is sufficient to cause this inversion of solubilities. Therefore the effect of cryptate formation with $(2,2,2)$ on the solubility product of $\mathrm{KClO}_{4}$ changes from a decrease in water to an increase in acetonitrile.

\section{REFERENCES}

1. C.J. Pedersen, J. Am. Chem. Soc. 89, 2495, 7017 (1967), Aldrichimica Acta 4, 1 (1971)

2. C.J. Pedersen, in 'Synthetic MuTtidentate Macrocyclic Compounds', Eds. R.M. Izatt, J.J. Christensen, p. 1, Academic Press 1978

3. C.J. Pedersen, Angew. Chemie 100, 1053 (1988)

4. B. Dietrich, J.-M. Lehn, and J.-P. Sauvage, Tetrahedron Lett. 2885, 2889 (1969)

5. J.-M. Lehn, Struct. Bonding (Berl in) 16,1 (1973)

6. J.-M. Lehn, Angew. Chem. Int. Ed. 27,89 (1988)

7. B.G. Cox, J. Garcia-Rosas, andH. Schneider, J. Am. Chem. Soc. 103, 1384 (1981)

8. A.F. Danil de Namor, L. Ghousseini and W.H. Lee, J. Chem. Soc., Faraday I, 81, 2495 (1985)

9. D. Moras, B. Metz, and R. Weiss, Acta Crystallogr. Sect. B, B29, 383 (1973)

10. M.E. Lejaille, M.H. Livertoux, G. Guidon, and J. Bessierre, BüT. Soc. Chim. France I-373 (1978); J. Bessière and M.F. Lejaille, Anal. Lett. 12, 753 (1979)

11. J. Gutknecht, H. Schneider, and J. Stroka, Inorg. Chem. 17, 3326 (1978)

12. M.K. Chantooni, Jr. and I.M. Kol thoff, J. Soln. Chem. I4, i (1985)

13. A.F. Uanil de Namor, H. Berroa de Ponce, and E.C. Viguria, J. Chem. Soc., Faraday 1, 82, 2811 (1986)

14. A.F. Danil de Namor and H. Berroa de Ponce, J. Chem. Soc. Faraday I, 83, 1569 (1987)

15. A.F. Danil de Namor, F.F. Salazar, and P. Greenwood, J. Chem. Soc., Faraday I, 83, 2663 (1987)

16. A.F. Danil de Namor and L. Ghousseini, J. Chem. Soc. Faraday I, 81, 781 (1985)

17. A.F. Danil de Namor, L. Ghousseini, and T. Hili, J. Chem. SoC. Faraday I, 82, 349 (1986)

18. A.F. Danil de Namor and L. Ghousseini, J. Chem. Soc. Faraday I, 82, 3275 (1986)

19. B.G. Cox, P. Firman, J. Garcia-Rosas, and H. Schneider, Tetrahedron Lett. 23, 3777 (1982)

20. A. Mei, A.I. Popov, and J.L. Dye, J. Am. Chem. Soc. 99, 6532 (1977)

21. M.H. Abraham, A.F. Danil de Namor and R.A. Schulz, J. Chem. Soc. Faraday I, 76, 869 (1980)

22. 'Selected Values of Chemical Thermodynamic Properties', U.S. National Bureau of Standards, Circular 500 and supplementary Technical Notes

23. R.M. Izatt, J.S.Bradshaw, S.A.Nielson, J.D.Lamb and J.J.Christensen, Chem. Rev. 85, $271(1985)$

24. A.F. Danil de Namor and L. Ghousseini, J.Chem.Soc. Faraday I, 80, 2349 (1984)

25. A.F. Danil de Namor, J. Chem. Soc. Faraday 1, 88, 2441 (1988)

26. B.G. Cox, C. Guminski and H. Schneider, J.Am.Chem.Soc. 104, 3789 (1982)

27. B.G. Cox, P. Firman, D. Gudl in and H. Schneider, J.Phys.Chem. 86, 4988 (1982) 